\title{
The Effect of Teachers' Attitudes Towards Collaborative Instruction on Students' Writing and Speaking Skills
}

\author{
Tareq Murad \\ The Department of English Language and Literature, Sakhnin College, Israel \\ Yusra Ghadeer, Sakhnin \\ College for Teacher Education, Sakhnin College, Israel \\ Jamal Assadi \\ The Department of English Language and Literature, Sakhnin College, Israel
}

\begin{abstract}
The current study seeks to examine English teachers' attitudes towards using the collaborative teaching method to improve students' skills at writing and speaking English. The purpose is to test the main following hypotheses: first, English language teachers are mostly unfamiliar with collaborative learning. Second, these techniques are not regularly used in English lessons. Third, most students enjoy practicing them. Fourth, these techniques lead to better performance in the students' language skills. The study was conducted among 15 high school English teachers. A questionnaire was used as a practical part. Data were collected and the results were: English teachers know and support learning techniques; they agree on the importance of these methods in the teaching process especially in improving students` language skills. Students enjoy practicing them. Common suggestions were proposed by the teachers for improving writing and speaking skills such as involvement of students in planning the learning process and setting goals and allowing for selfexpression and teamwork. The importance of using various learning tools in combination with the collaborative methods was also emphasized. Finally, the research recommends that this kind of learning should be part of the teachers' training program.
\end{abstract}

Index Terms - collaborative learning, speaking skill, writing skill, EFL

\section{INTRODUCTION}

Language is considered as a global communication tool that is used for different purposes such as personal and social communication, business exchange, politics, training and more (Wilson, 1997).

Recently, there has been a change in the learning models used in the English language; the learning models have become learner-centered models. This change indicates a development in the field of learning where English teaching should allow students to express themselves using the spoken language. Therefore, discourse is one of the most essential skills for continuity, progress and interpersonal communication (Leong \& Ahmadi, 2017).

Communication and interaction skills in most classes should not be considered the solely tools that can provide students with the ability to conduct a conversation and develop questions, or with ways that can advance their thinking techniques, upgrade group communication, empower other abilities such as studying habits. Combining these abilities in the learning process will improve the ability of communications among the students. Teachers need to implement educational strategies that encourage the acquisition of important learning skills. Collaborative strategy may serve as an approach that provides this; it serves as an elective way of instructing discourse and social interaction between students and teachers. It also enables students to examine, think about, and draw conclusions on given subjects. Students are free to experience emotions, contemplations, or goals that have emerged during the lesson.

Speaking and writing skills are called productive skills. They are important as they give students the chance to practice real-life activities inside the classroom. Discourse in spoken or written language in a given context is intended to achieve communication among the target audience and is regarded as a major pedagogical tool used by the teacher. It has been noticed that learners who interact and speak are able to achieve better in oral skills in most cases than those who always keep silent (Namaziandost, Hashemifardnia, \& Shafiee, 2019).

The organization of classroom teaching is derived from the teachers own pedagogical concept and influences the discourse and the rules of participation and interaction in the classroom. Therefore, teaching is an interactive process through which a classroom discourse takes place. It is important to expose teachers to a variety of existing and new pedagogical models around the world to ensure continuous development among them in such a way that can affect the education system in general and students in particular. Teachers must receive the training, support and security to change teaching methods at Israeli schools. Active and inclusive learning must be fostered. Teachers must teach 
students to observe, know, and explore their environment. They also should encourage collaborative activities with peer students, which help in processing and analyzing information and implementing it in real-life situations. It is important to involve students in group work that develops mutual awareness and engagement, so that they can become accountable (Vygotsky, 1978).

\section{LITERATURE REVIEW}

\section{A. Collaborative Learning}

Collaborative learning is characterized as an educating strategy in which students are engaged to examine specific subjects of study, while teachers serve as guides or facilitators who share insights. As an instructive approach, it demonstrates the organization of classroom exercises in academic and social learning experiences (Siltala, 2010). According to Cooper (1990), collaborative learning is attributed to the act of giving students the chance to work with others, so they do some work in groups or pairs. Different names have been given to it such as collaborative learning, cooperative learning, collective learning, team learning, learning communities and reciprocal learning.

Many studies have examined the impact of using a collaborative learning method on speech skills. Much of the research indicates the contribution of the collaborative method to creating a positive attitude towards group learning and increased speech skills (Nasri \& Biria, 2017).

Unlike traditional learning methods, collaborative learning has certain advantages that are mainly derived from social interaction between students (Tahmasbi, Hashemifardnia, \& Namaziandost, 2019).

To improve student speaking skills, teachers most often adopt collaborative learning activities such as group discussions, or role-playing to help students learn phrases which they were exposed to while using this method (Li, 2015). The terms accompanying activities are arranged in such a manner that allows them to be easily implemented. These activities relied on the collaborative learning approach to improve students' academic ability during group learning (Kagan, 1994).

Students are satisfied with helping others and their participation in the group effort, their sense of increased control, and their responsibility for learning affect their motivation for learning. Johnson and Johnson (2009) note that the more students endorse collaborative attitudes, the more they consider themselves to be intrinsically motivated. This can increase their persistence in achieving their goals, shared efficacy, and desire to learn.

Dweck (2012) claimed that only teachers who adopt a positive attitude towards cooperative learning can promote and practice it within their classes. Researchers have concluded that teachers' negative attitude towards cooperative learning is an important obstacle for its implementation in schools (Gillies, 2014; Roseth, Johnson, \& Johnson, 2008). Their attitude may be partly due to the demands imposed by institutions, as well as their lack of knowledge and proficiency (Gillies \& Boyle, 2010; Kohn, 1992).

According to Hennessey \& Dionigi (2013), teachers who had previous training and knowledge managed to guide their student's negative attitudes to some more positive ones on collaborative learning. Gillssies and Khan (2008) also found out that the schools whose teachers had already been trained to implement cooperative learning achieved better results than those who had not been trained in this instruction.

Thus, it seems important for teachers to know how to implement cooperative learning in their teaching process.

\section{The strong points of cooperative learning in EFL classroom}

With the growing emphasis on communicative language teaching, many benefits of collaborative learning have been brought into the context of the foreign language classroom. According to Crandall (1999), practicing speaking in groups helps students to explore different sides of language and allows them to develop new thought patterns. He also mentions the impact of collaborative language learning in reducing students' anxiety, enhancing positive attitudes toward language learning and improving self-esteem, and encouraging students' autonomy.

Grath (2000) showed the benefits of collaborative learning in four categories:

1. social benefits:

- Cooperative learning develops social support system for students.

- It builds a range of understanding among learners and educational staff.

- It establishes a positive climate for practicing cooperation.

- It develops learning communities.

2. Psychological advantages:

- The collaborative instruction gives the learners a lot of attention and puts them at the center; in addition, it

helps increase confidence and self-image.

- Cooperation decreases anxiety

- Collaborative learning develops positive attitudes towards teachers.

3. Academic merits:

- It strengthens critical thinking skills.

- It models appropriate problem-solving techniques.

\section{Possible disadvantages of group learning in the foreign language context}

Students' participation in collaborative activities may be uneven. Some students will be more responsible for the tasks assigned to them than others (Thornton, 1999). To prevent this, teachers should supervise students while performing 
collaborative tasks regularly. The group assignment should be divided among the students so that each student will have to perform a particular part, and at the end of the assignment, each student will be required to submit a feedback and a personal assessment in which he explains the work process, learning experience, problems he encounters, solutions, feelings and preferences and more.

Pica (1994) added that students are less likely to pay attention to foreign language structures with a lack of teacher involvement, and then they tend to use the native language. Furthermore, Richards and Rodgers (2001) pointed out that collaborative learning puts an additional burden on teachers who are required to play different roles in the classroom.

Although the teacher is required to perform various roles alongside being a teacher, he must teach in a way that ensures proper learning for the students. The mother tongue is used only when explaining the instructions. In other cases, the teachers should encourage the exclusive use of the English language during the lesson. Technological and other learning tools can be used to expose students to the English language and enhance learning among them.

Teachers could talk about the way people use language in terms of language skills: reading, writing, speaking and listening. They are often divided into two kinds: "Receptive skills" is a term used for reading and listening skills where meaning is derived from the discourse, while "productive skills" is the term used for speaking and writing skills where students actually have to create language themselves (Harmer, 2007).

\section{B. Speaking Skill}

Speaking is the productive skill that refers to the production of speech sounds. It is defined as the literal use of language and the means of communication between humans. It is used to express some ideas, messages or emotions in a spoken language to make the other side understand the messages being delivered (Fulcher, 2003). According to Chastain (1998), speaking is a productive skill that involves many components, such as grammar, strategy, sociolinguistics and discourse. For him, speaking is more than simply making the right sounds, choosing the right utterances or getting the constructions correct.

According to Doff (1988), there are three kinds of speech modes:

- interactive: these situations include face to face interactions or phone calls, in which we listen and talk intermittently, and have a chance to ask for simplifications, repetition or slower speech from our counterparts.

- Partially interactive: giving a speech to a live people can serve as an example of a partially interactive conversational situation where the audience does not interfere with the speech. The speaker can see the audience and judge by the expression on their faces and body language whether the speech is understood or not. radio broadcast.

- Non-interactive: some few speaking situations may be non-interactive, such as when recording a speech for a

\section{Speaking activities}

Types of speaking activities (Byrne, 1987):

a. Groupings: Finding ties among other students, when creating groups, teacher and learners need to converse what they will discuss.

b. Picture stories: students interpret a story based on a picture sequences. They work collaboratively to put the story in the correct order.

c. Problem solving: Learners work together to come up with solutions to the problem.

d. Drama and Role-play: Students can explain themselves in a variety of ways and may be transported into a world of imagination. Using drama in the classroom setting provides a useful and enjoyable medium to discover language.

Although dialogues and conversations are used most often, a teacher can select activities from a variety of tasks. Brown (1994) lists six possible task categories:

a. Imitative-Drills in which the learner simply repeats a phrase or structure for clarity and accuracy.

b. Intensive-Drills or repetitions where the learner sheds light on specific phonological or grammatical points, such as minimal pairs or repetition of a series of imperative sentences.

c. Responsive: Short replies to teacher or learner questions or comments, such as a series of answers to yes/no questions.

d. Transactional: Dialogues conducted for the purpose of information exchange, such as informationgathering interviews, role plays, or debates.

e. Interpersonal: Dialogues to establish or maintain social relationships, such as personal interviews or casual conversation role plays.

f. Extensive: Extended monologues such as short speeches, oral reports, or oral summaries.

Certain requirements need to be met when using activities for better learning. To apply this to speech, some suggestions are given as follows:

1. Encourage students to talk a lot.

2. Allow students to participate equally.

3. Increase motivation among students.

4. Use an acceptable level of language (Byrne, 1987).

\section{Problems with speaking activities}


Students may encounter some difficulties during speaking activities that may affect the learning process. Here are some possible difficulties suggested by Park \& Lee (2005):

1. Students are afraid to make mistakes in class, feel afraid of criticism and become shy and closed.

2. Students may feel unmotivated to express themselves and participate in speech when they are not interested in the lesson.

3. When all students share the same mother tongue, students tend to use it because it is easier.

\section{Solving the problems}

To solve the possible problems, Byrne (1987) suggested the following:

1. Conducting group work: This activity can encourage openness, acceptance of the other, cooperation, and partnership and increases self-confidence among students.

2. The use of easy language: A choice of a topic and language that suits the level of the students and does not make it difficult for them to understand or reduce the motivation to learn.

Both tasks require giving clear instructions.

English language has evolved and its use has increased in the world, leading it to a status higher than before. English has become important in various aspects of life. It has become associated with advancements in technology, commerce, tourism, science, politics and more. As a result, the speaking ability is necessary. Teachers must train students to develop their oral communication. According to Brown (2007), there are three components of oral communication. The first is defined as the ability to speak spontaneously and eloquently. Next comes accuracy, which is defined as the control of phonological, grammar, and discourse elements. It also refers to linguistic ability. The last element is pronunciation and is defined as the production and perception of the significant sounds of a particular language in order to achieve meaning. In summary, fluency, accuracy, and pronunciation are important and complementary elements in the development of student speech skills.

\section{Writing Skill}

Writing is one of the educating skills that include complex exercises such as developed thinking, interpreting thoughts and reflections. Writing requires a significant exposure to information about lexical, syntactic, and dialect standards to deliver precise work (David et al., 2015). In his social constructivist hypothesis, Vygotsky (1978) emphasized that dialect instructors require comprehensive preparations to increase students' dialectical ability during group learning, and to strengthen individual abilities during individual learning.

Writing skills are determined by the final product performance of the students in which they were required to create new work according to a predetermined standard (Richards and Rodgers, 1982).

In order to improve the writing skills of English language learners, teachers must consider new and innovative methods for their instruction as mentioned below:

1. Activating prior knowledge: Cooperative learning helps students gain more background knowledge. Students collect information as they work together with another student or a group of students. Through this strategy, students not only gain additional information needed to complete the writing assignment, but also obtain a great opportunity to develop language skills through peer-led conversations (Storch, 2007).

2. Using technology: The rise of technology integration has significantly contributed to the change in teaching methods in a second language. It motivates and encourages students to engage in reading and writing, and the various ways in which it is used prove beneficial in cultivating writing skills among this population of students (Lee, 2012).

3. Journal writing: the implementation of an interactive journal greatly benefits English language learners as it motivates them to write more in length and richer in content (Lee, 2012).

\section{METHODOLOGY}

\section{A. Research Objective}

The main purpose of this study is to examine English teachers`attitudes towards collaborative teaching method and implementing writing and speaking students`skills in English lessons. The goal is to improve students`writing and speaking skills and to familiarize English teachers with collaborative learning techniques so that they can encourage learners to practice these techniques.

\section{B. Research Method}

The approach used for this study is a qualitative research method. This type of method focuses on obtaining data through open-ended and conversational communication. It also involves data collection of personal experiences, introspection, stories about life, interviews, observations, interactions and visual texts which are significant to people`s life. (Radu, 2019)

The current study attempts to uncover teachers' attitudes towards the collaborative school teaching method and the assimilation of reading and writing skills in an English lesson. It also examines the difficulties and recommendations that will lead to an improvement in the assimilation of these skills. 


\section{Research Participants}

The research population of this study consisted of fifteen Arab English teachers who teach at Arab high schools in the north. Nine of them are females and six are males. Nine of them studied for a master's degree compared to six who studied for BA only. The age range was divided into two groups; in the first group the age was within the years 24-30, and in the second group the age was within 40-58. The seniority was divided accordingly; in the first age group, the seniority ranged from 1-5 years while in the older age groups the seniority was more than 15 years.

\section{Research Tools}

To collect the qualitative data of the present study, a questionnaire, including 10 items, was given to all participants. The questionnaire introduces the population and study sample showing some of their characteristics and education. Data were assembled and structured as a theoretical part. The advantages of such a tool are that it allows uniformity in the collection of information from the respondents; it does not take much time; the analysis of the data is relatively simple and objective, and there is a convenient option to compare the different respondents' answers.

\section{E. Data Collection}

The sample is small and unrepresentative but may be unique. Data were collected through written questioner. The researchers talked with them over phone and met them individually. The researchers explained the questionnaire and the objective of the study to the participants clearly. The teachers got time to think and answer the open-ended questions quite clearly.

The validity and reliability of the study were examined based on Maxwell's theoretical model (Maxwell, 1992). An optimal examination of the levels of validity requires a repetition of the interviews, but this possibility is not realistic, as argued in qualitative studies (Sabar Ben-Yehoshua, 2001). Therefore, factors that may interfere with validity, accuracy and the ability to generalize were examined. An effort has been made to prevent various factors to impair validity and reliability in order to testify indirectly (through negation) about high dimensions of validity and reliability of the research tool (Maxwell, 1992).

The characteristics of the used questionnaire:

1. The literature shows that a short questionnaire leaves only a "first impression" and indicates unreliability (Ben Simon and Nevo, 1986). The current research tool included demographic questions and ten openended questions.

2. Variety of topics in the questionnaire - a larger number of topics allows an examination of different and varied aspects of the personality of the research participants. In the present study each question addressed a different topic.

3. The questionnaire was conducted anonymously without the researcher's ability to intervene and influence the respondents.

\section{F. Data Analysis}

The process of analyzing data in qualitative research is a process of arranging and analyzing the information collected in order to interpret and understand the meanings of this data (Shakedi, 2004).

The examination of the information within the study can be done in a variety of strategies (by categories, selection instruments, and more), and the foremost common of which is categorized investigation. The product of the analysis is thematic categories. According to this and in accordance with the research questions, the main research identifies key categories that relate to the research concept.

In the analysis phase the researchers coded each interview separately. The coding unit was a sentence or paragraph that provided the context of the questions in the interview. For example, teachers' attitudes from the collaborative method, methods were applied to assimilate speaking skills and writing English were coded into unites for analyzing data.

Due to the global outbreak of the COVID-19 virus, it was not possible to distribute the questionnaires to some of the participants, so they were asked to write their answer using Microsoft Word and send via email.

A full and constant explanation of the questions was given to the participants in order to avoid possible deviation and misunderstanding.

\section{FINDINGS}

The purpose of the current study was to examine English teachers' attitudes towards the Collaborative teaching method and implementing writing and speaking skills in English lessons.

The study also sought to explore the various skills or qualifications required to practice this method, problems that teachers face in the English teaching process, students` reactions to the method during English lessons, ways to enhance students' involvement in English lessons, and attitudes towards learning.

Research data were collected during June and July 2020. The qualitative findings were based on collecting the respondents' answers into categorization and classification for analysis. Fifteen teachers participated in the study. They are all teachers who teach English at high schools. Nine of them are females while six are males. $60 \%$ of them studied 
for a master's degree compared to $40 \%$ who studied for BA only. The age range was divided into two groups; in the first group the age ranged from 24-30, and in the second group, the age ranged from 40-58. The seniority was divided accordingly; in the first age group, the seniority ranged from 1-5 years while in the older age groups the seniority was more than 15 years.

The researchers have chosen to present the data in the table below where the topics are presented by category in a way that facilitates understanding.

CATEGORIES RAISED FROM THE STUDY:

\begin{tabular}{|c|c|}
\hline Category & \\
\hline $\begin{array}{l}\text { The attitude of teachers towards the Collaborative } \\
\text { Method. }\end{array}$ & $\begin{array}{l}14 \text { of the participants expressed a positive attitude towards the use of the } \\
\text { collaborative learning method. They also supported their opinion in noting the } \\
\text { mutual benefit between students and teachers and between students and } \\
\text { themselves. The benefit was expressed in a variety of forms. Below are quotes } \\
\text { from the respondents. } \\
\text { Positive } \\
\text { "Weak pupils can learn from better ones" (respondent } 1 \text { ) } \\
\text { "It strengthens the relationship between teacher and his students and among } \\
\text { themselves." (respondent } 2 \text { ) } \\
\text { "It improves teaching." (respondent } 3 \text { ) } \\
\text { "It is the way to exchange ideas." (respondent 5) } \\
\text { "It actively engages students through defending their opinions, reframing ideas, } \\
\text { and listening to other viewpoints." (respondent 14) } \\
\text { Negative } \\
\text { "Each teacher has his/her own style. It doesn t always work perfectly." } \\
\text { (respondent 4) }\end{array}$ \\
\hline The attitude of students during English lessons. & $\begin{array}{l}\text { Most teachers }(60 \%=9) \text { reported a positive attitude of students to the } \\
\text { collaborative method. Six teachers pointed out obstacles that caused a negative } \\
\text { attitude among the students as quoted below. } \\
\text { Positive } \\
\text { "Positively, it makes a change in a regular lesson." (respondent 3) } \\
\text { "They are happy." (respondent 7) } \\
\text { "They get more involved." (respondent 15) } \\
\text { Negative } \\
\text { "Loud noise." (respondent 14) } \\
\text { "They don't interact properly." (respondent 2) } \\
\text { "They face problems with vocabulary and are afraid to be laughed at." } \\
\text { (respondent 8) } \\
\text { "They may face some problems due to lack of collaborative skills." (respondent } \\
\text { 9) }\end{array}$ \\
\hline $\begin{array}{l}\text { Skills / Qualifications } \begin{array}{c}\text { required for practicing } \\
\text { collaborative method in English lesson. }\end{array}\end{array}$ & $\begin{array}{l}\text { Reading and speaking skills, individual and social skills (like: Individual } \\
\text { accountability, self-confidence, effective communication, team working, open- } \\
\text { mindedness, tolerance), monitoring and management. }\end{array}$ \\
\hline $\begin{array}{l}\text { Ways to enhance students' involvement in English } \\
\text { lessons. }\end{array}$ & $\begin{array}{l}\text { Involve students in the planning of teaching process, create interest among } \\
\text { students through their participation in setting goals, draw attention to students, } \\
\text { initiate class discussions, and integrate technological tools. }\end{array}$ \\
\hline $\begin{array}{l}\text { Ways to foster positive attitudes towards learning } \\
\text { English. }\end{array}$ & $\begin{array}{l}\text { Facilitating the learning process, making the learning process accessible, } \\
\text { developing an active exchange of ideas, exposing students to different styles of } \\
\text { teaching, and providing a comfortable learning environment. }\end{array}$ \\
\hline $\begin{array}{l}\text { Contribution of collaborative teaching methods in } \\
\text { motivating students to develop writing and speaking } \\
\text { skills. }\end{array}$ & $\begin{array}{l}\text { The collaborative method helps students accept the other and improve social } \\
\text { and learning skills especially teamwork and exchanging opinions and ideas. It } \\
\text { allows for personal expression as well. }\end{array}$ \\
\hline $\begin{array}{l}\text { Observed changes in speaking and writing English } \\
\text { skills while practicing the collaborative method. }\end{array}$ & $\begin{array}{l}\text { There is an improvement in the ability to speak and write and gain vocabulary. } \\
\text { Students are more challenged to participate in discussions and teamwork. }\end{array}$ \\
\hline $\begin{array}{l}\text { Activities for improving speaking and writing in } \\
\text { English lesson. }\end{array}$ & $\begin{array}{l}\text { Role-playing, presentations, watching educational moves/videos, reporting daily } \\
\text { diary, postcards, letters, practices games, problems-solve tasks. }\end{array}$ \\
\hline New values & $\begin{array}{l}\text { Team-work, mutual respect, decision making, haring, helping, problem-solving, } \\
\text { accept different opinions, and competition. }\end{array}$ \\
\hline Suggestions for improving speaking and writing skills. & $\begin{array}{l}\text { Uniting summaries, exposure to new vocabulary items, constant supervision of } \\
\text { teachers, and use of constantly enriching activities such as presentations, story } \\
\text { creation, mini-scientific research, play and other individual and group activities. }\end{array}$ \\
\hline
\end{tabular}

The data indicate ten categories that reflect the attitudes, opinions and recommendations of teachers regarding the collaborative teaching method and implementing writing and speaking skills in English lessons.

A large majority of teachers $(93 \%)$ expressed a positive attitude towards the collaborative method. They claimed that this method contributes to the improvement of the learning process and imparts social values such as mutual respect, cooperation, help and support as well as improvement in academic achievement. The students gain self-confidence, and they enjoy working in teams. When teachers were asked about their students' attitudes towards this teaching method during English lessons, nine teachers stated that the students' attitudes were positive and made similar claims to what they had among the students as well.

Students enjoyed the collaborative method because they felt they were part of the learning process and that it instilled self-confidence, teamwork and mutual respect. In contrast, six teachers noted that this method caused excess noise and 
disorder. Students also demonstrated a lack of command of English language skills. Their vocabulary was poor which affected the individual and group communication during the lesson.

For practicing collaborative method in English lesson teachers agreed on the importance of reading and writing skills, individual and social skills, like individual accountability, self-confidence, effective communication, team working, open-mindedness, tolerance, monitoring and management. To enhance students` involvement in English lessons students must be involved in the teaching process` planning, setting goals and class discussions. Teachers should use integrating technological tools during lessons to motivate students.

Teachers suggested using a variety of technological tools such as Google Forum, online chat, video and projector and more in order to increase interest among students and facilitate the English learning process. To foster positive attitudes towards learning English they also agreed to facilitate the learning process, make the process accessible, develop an active exchange of ideas, expose students to different styles of teaching and provide a comfortable learning environment

Observed changes in speaking and writing English skills while practicing collaborative method lead to an improvement in the ability to speak and write as well as vocabulary enrichment. Students are more challenged to participate in discussions and teamwork. Suggestions for improving speaking and writing skills include the following activities: Role-playing, presentations, watching educational moves/videos, reporting daily diaries, writing post-cards, and letters, playing games, conducting problems-solve tasks, writing summaries, dealing with new vocabulary items, presentations, story creation, mini-scientific research, and other individual and group activities. These activities must be performed under constant supervision of teachers.

Team-work, mutual respect, decision making, sharing, helping, problem-solving, accepting different opinions and competition are values that students gain when practicing collaborative method during English lessons.

\section{DiSCUSSION AND CONCLUSION}

The purpose of this study was to examine the effect of teachers' attitudes towards collaborative instruction on students' writing and speaking skills. In addition, it investigated the skills or qualifications entailed to perform this method, problems that teachers encounter in English teaching process, students` responses to the method during English lesson and techniques to boost students' engagement in English lesson and outlooks towards learning.

The findings were reminiscent to those reached by Nasri and Biria (2017), who indicated positive attitudes of teachers toward the collaborative method in the learning process, and the impact of using this method on speech skills. This current study also pointed at complete agreement on a positive attitude toward this method among teachers. The teachers agreed that this method helps in improving the speaking and writing skills in the English lesson.

The findings from the study also indicated that collaborative teaching method helps students to develop selfconfidence and motivation, cooperation and mutual respect, tolerance and teamwork, gaining new vocabulary and more. These findings were also similar to those of a study done by Tahmasbi, Hashemifardnia and Namaziandost (2019), who declared that collaborative learning, unlike traditional learning methods, has certain advantages that are derived mainly from social interaction between students.

However, it is very important to relate to students as partners in the learning process through planning and setting goals. Most of the effective activities that help in the learning process and are integrated with collaborative learning necessitate a combination of smart methods such as role-playing, doing presentations, writing postcards and others that include technological tools such as Google Forum, online chat and video watching. The findings received from the current research are similar to the findings from the study of Li (2015). In his research Li suggested to improve student speaking skills by adopting collaborative learning activities such as group discussion and role-playing aimed at helping students learn phrases they were exposed to as a result of using this method (Li, 2015).

\section{RECOMMENDATIONS}

The study introduces some recommendations. These are:

1. The concepts of collaboration should be taught at the colleges for teacher education

2. EFL teacher education programs should be rebuilt by extending student teaching, and integrating field experience components into their coursework so that teaching methodology can reflect curriculum goals, and teachers' experience.

3. EFL teachers should motivate their students and show patience in order to train them and improve language production and use.

4. Syllabus designers have to devote enough time for collaboration supplemented with a variety of activities for practicing group and pair work.

\section{REFERENCES}

[1] Brown, H. D. (2007). Teaching by principles. (3rd ed.). London: Longman.

[2] Byrne, D. (1987). Techniques for class room interaction. London: Longman, pp 83-85.

[3] Chastain, K. (1998). Developing second language skills (2nd Ed.). Chicago: Harcourt Brace Publishers.

[4] Cooper, J. (1990). Cooperative learning and college instruction. State University: pp 6-7. 
[5] Crandall, J. (1999). Cooperative language learning and affective factors. In J. Arnold (Ed.). Affect in language learning (pp. 226-245). Beijing, China: Foreign Language Teaching and Researching Press.

[6] David, A.R., Thang S.M. \& Azman, H. ( 2015). Accommodating low proficiency ESL students' language learning needs through an online writing support system. E-Bangi Journal, 10(1): 118-126.

[7] Doff, A. (1988). Teach English. A training course for teachers. Cambridge: University Press, pp 65-67.

[8] Dweck, C.S. (2012). Mindsets and human nature: Promoting change in the Middle East, the schoolyard, the racial divide, and willpower. American Psychologist, 67(8), 64-622.

[9] Fulcher, G. (2003). Testing second language speaking. London: Longman/Pearson Education.

[10] Gillies, R. M., \& Boyle, M. (2010). Teachers` reflections on cooperative learning: Issues of implementation. Teaching and Teacher Education, 26(4), 933-940.

[11] Gillies, R. M. (2014). Cooperative learning: Developments in research. International Journal of Educational Psychology, 3(2), 125-140.

[12] Gillies, R. M., \& Khan, A. (2008). The effects of teacher discourse on students` discourse, problem-solving and reasoning during cooperative learning. International Journal of Educational Research, 47(6), 323-34.

[13] Grath, Mc. (2000). Strengthening collaborative work. UK: project-based learning, pp 71-74.

[14] Harmer, Jeremy. (2007). The practice of English language teaching. 4th ed. London: Longman.

[15] Hennssey, A. \& Dionigi, R. A. (2013). Implementing cooperative learning in Australian primary schools: Generalist teachers` perspectives. Issues in Educational Research, 23(1), 52-68.

[16] Johnson, D. W., \& Johnson, F. (2009). Joining together: Group theory and group skills (10th ed.). Boston: Allyn \& Bacon.

[17] Kagan, S. (1994). Cooperative learning. San Clemente: Kagan Publishing.

[18] Kohn, A. (1992). Resistance to cooperative learning: Making sense of its deletion and dilution. Journal of Education, 174, 3855.

[19] Lee, H. (2012). The reading response e-journal: An alternative way to engage low-achieving EFL students. Language Teaching Research, 17 (1), 111-131.

[20] Leong, L. M., \& Ahmadi, S. M. (2017). An analysis of factors influencing learner's English speaking skill. International Journal of Research in English Education, 2(1), 1-34

[21] Li, L. (2015). Cooperative learning in the course of English listening and speaking in independent college: A case study of Bowen College of management (Master's thesis). Retrieved from CNKI Dissertations and Theses database.

[22] Maxwell, J. (1992). Constructive, interpretive approaches to human inquiry. In: N. K. Denzin \& Y. S. Lincoln (Eds.) Handbook of qualitative research (pp. 118-137). Thousand Oaks, CA: Sage.

[23] Namaziandost, E., Hashemifardnia, A., \& Shafiee, S. (2019). The impact of opinion-gap, reasoning-gap, and information-gap tasks on EFL learners' speaking fluency. Cogent Social Sciences, 5, pp 57-59.

[24] Nasri, M., \& Biria, R. (2017). Integrating multiple and focused strategies for improving reading comprehension and 12 lexical development of Iranian intermediate EFL learners. International Journal of Applied Linguistics \& English Literature, 6(1), 311-321.

[25] Park, H., \& Lee, A. R. (2005). L2 Learners' anxiety, self-confidence, and oral performance. Proceedings of the 10th Conference of Pan-Pacific Association of Applied Linguistics (pp. 107-208).

[26] Pica, T. (1994). Research on negotiation: What does it reveal about second language learning conditions, processes, and outcomes? Language Learning, 44, 493-527.

[27] Richards, J.C., \& Rodgers T. (1982). Method: Approach, design, and procedure. Tesol Quarterly, 16(2): 153-168.

[28] Radu, V. (2019). Qualitative research: Definition, methodology, limitation, examples. Retrieved from Ecommerce Grouth: https://www.omniconvert.com/blog/qualitative-research-definition-methodology-limitationexamples.html\#What_is_qualitative_research. May, 2020.

[29] Richards, J. C., \& Rodgers, T. S. (2001). Approaches and methods in language teaching. Boston, MA: Cambridge University Press.

[30] Roseth, C. J., Johnson, D. W., \& Johnson, R., T. (2008). Promoting early adolescents` achievement and peer relationships: The effects of cooperative, competitive, and individualistic goal structures. Psychological Bulletin, 134(2), 223-227.

[31] Shkedi, A. (2004). Narrative survey: Methodology for studying multiple populations. Narrative Inquiry, 14 (1): 87-111.

[32] Siltala, R. (2010). Innovatively and cooperative learning in business life and teaching. Turko, Finland.

[33] Storch, N. (2007). Investigating the merits of pair work on a text editing task in ESL classes. Language Teaching Research, 11(2), 143-159.

[34] Tahmasbi, S., Hashemifardnia, A., \& Namaziandost, E. (2019). Standard English or world Englishes: Issues of ownership and preference. Journal of Teaching English Language Studies, 7(3), 83-98.

[35] Thornton, P. (1999). Reading together. In D. Kluge \& S. McGuire (Eds.), JALT Applied Materials: Cooperative Learning (pp. 23-36). Tokyo, Japan: Japan Association for Language Teaching.

[36] Vygotsky, L. (1978). Mind in society: The development of higher psychological processes. Cambridge: MA Harvard University Press.

[37] Wilson, Julie Anne. (1997). A program to develop the listening and speaking skills of children in a first grade classroom. Research Report, [ED415566]

Tareq M. Murad has been teaching English as a foreign language in high schools since 1990, and he has been teaching linguistic courses in Sakhnin College, Academic College for Teacher Education since 2001. Recently, he holds a position in the College: The head of the practicum department. Courses: Intro to linguistics, Semantics, pragmatics and teacher education. He has BA in English linguistic and literature from Ben-Gurion University, MA in English Linguistics from Haifa University, Pedagogical supervision from Machon- Mofet. TA and PhD in English curricula and Instructions from Yarmouk University. 
Research interests: pragmatics: speech acts, second/foreign language acquisition and task-based language teaching (TBLT). The author has many publications in local and international Journals, the most recent of them are: Murad, T. (2011). The Effect of TaskBased Language Teaching on Developing Speaking Skills among the Palestinians Secondary EFL Students in Israel and Their Attitudes towards English. www.asian-efl-journal.com/Thesis/Thesis-murad pdf. Murad, T., \& Shaalta, J. (2012). A contrastive Linguistic analysis between Arabic and English. In Arabic. Sakhnin college. Assadi,N.; Murad, T. and Khalil, M. (2019). Training teachers' perspectives of the effectiveness of the academy class training model on trainee's professional development. Journal of theory and practice in language studies, 9, (2), 137-145.

Yosra Ghader is an EFL for 15 years in different High schools in Israel. She recently got her second degree in English curriculum and instruction.

Research interests: teaching English as a second or foreign language and second language acquisition

Jamal Assadi, associate professor, chairs the Department of English (Mteach, Secondary \& Elementary Tracks--Regular and Supplementary studies), coordinator of English for Academic Purposes at The College of Sakhnin, and a former lecturer at An-Najah National University, Nablus. He received his Ph.D. in English literature from the University of Newcastle Upon Tyne in England. In addition to numerous articles in professional journals, and children's stories. Prof Assadi is the author of Acting, Rhetoric and Interpretation in Selected Novels by F. Scott Fitzgerald and Saul Bellow (2006), co-editor of A Distant Drummer: Foreign Perspectives on F. Scott Fitzgerald (2007), co-author of The road to self-revival: Sufism, heritage, intertextuality and meta-poetry in modern Arabic poetry (2011) and Short fiction as a mirror of Palestinian life in Israel, 1944-1967: Critique and anthology. (2016).

Prof. Assadi also translated a few volumes of Palestinain peorty and short fiction to English. See Mohammad Ali Taha's "A Rose To Hafeeza's Eyes" And Other Stories (2008Loud Sounds from the Holy Land: Short Fiction by Palestinian Women (2011); The Story of a People: An Anthology of Palestinoan Poetry within the Green Line (2012) and Torn Body, One Soul: A Collection of Palestinian Short Fiction (2012). 